\title{
BIOACTIVE COMPOUNDS, ANTIOXIDANT ACTIVITY, AND MINERALS IN FLOURS PREPARED WITH TROPICAL FRUIT PEELS
}

\author{
L.B.S. SABINo* ${ }^{a *}$, M.L.C. GonZAGAa , D.J. SoAres ${ }^{a}$, A.C.S. Lima ${ }^{a}$, J.S.S. Lima ${ }^{a}$, \\ M.M.B. ALMeIDA ${ }^{b}$, P.H.M. Sousa ${ }^{c}$ and R.W. Figueiredo ${ }^{a}$

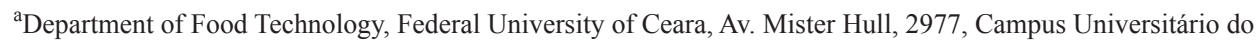 \\ Pici 60356-000, Fortaleza, Ceara. Brazil \\ ${ }^{b}$ Department of Analytical Chemistry and Physical Chemistry, Federal University of Ceara, Av. Mister Hull, 2977, \\ Campus Universitário do Pici, 60356-000, Fortaleza, Ceara. Brazil \\ cInstitute of Culture and Art, Federal University of Ceara, Av. Mister Hull, 2977, Campus Universitário do Pici, \\ 60356-000, Fortaleza, Ceara. Brazil
}

(Received: 9 April 2014; accepted: 29 June 2014)

\begin{abstract}
This study is aimed at performing the determination of bioactive compounds, antioxidant activity, and the identification of the minerals in the flours produced with the tropical fruit peels of mango, papaya, melon, and pineapple. The results showed that the papaya peel flour has the highest amount of ascorbic acid and lycopene when compared with the other studied flours. The mango peel flour has a high content of total extractable polyphenols and a high antioxidant activity. Regarding the mineral content, the by-product of melon stood out with $523.24 \pm 26.12$ $\mathrm{mg} / 100 \mathrm{~g}$ of potassium, $104.15 \pm 3.52 \mathrm{mg} / 100 \mathrm{~g}$ of calcium and $6.62 \pm 0.30 \mathrm{mg} / 100 \mathrm{~g}$ of iron. The flours prepared with mango, papaya, melon, and pineapple peels are potential sources of bioactive compounds and minerals, also presenting good antioxidant activity, being, therefore, recommended to be used in food products to improve the nutritional quality of the product.
\end{abstract}

Keywords: Ananas comosus L., Carica papaya L., Cucumis melo L., Mangifera indica L., nutritional value, trace elements

Tropical fruits, like mango, papaya, melon, and pineapple, being good sources of bioactive compounds (e.g. carotenoids and polyphenols), are recognized for their excellent nutritional value, which led to an increase in their consumption (SILVA et al., 2014).

Fruit and vegetable processing generates around one third of byproducts or waste (O'SHEA et al., 2012), constituting a form of environmental pollution, even representing a risk to human health (UCHOA et al., 2008; GAlindo-Estrella et al., 2009). It is known that many of these byproducts contain vitamins, minerals, fiber, and antioxidants that are important for physiological functions (Matias et al., 2005; FeliPe et al., 2006; Sousa et al., 2011; Silva et al., 2014), thus, the use of these byproducts in the production of new food products appears to be a nutritious alternative source of low cost.

Due to the growing commercialization and consumption of tropical fruit and the importance of the utilization of agro-industrial byproducts, this study aimed to quantify the bioactive compounds, the antioxidant activity, and the minerals in the flours produced with the tropical fruit peels of mango, papaya, melon, and pineapple, bringing important information on nutritional compounds in fruit by-products, characterized as an original research.

\footnotetext{
* To whom correspondence should be addressed. Phone: +55-85-86687879; fax: +55-85-33669752; e-mail: luno_ss@hotmail.com
} 


\section{Materials and methods}

Mango, papaya, melon, and pineapple were purchased in the local market of Fortaleza/ Ceara/Brazil. The description of each fruit cultivar and the selection criteria used are shown in Table 1.

Table 1. Type of fruit, their characteristics and drying conditions used in the determination of the bioactive compounds, antioxidant activity, and mineral content.

\begin{tabular}{lccc}
\hline Fruit & Cultivars & Appearance of the peel & $\begin{array}{c}\text { Drying temperature and } \\
\text { time }\end{array}$ \\
\hline Mango (Mangifera indica L.) & Coité & $\mathrm{GP} / \mathrm{NI}$ & $70^{\circ} \mathrm{C} / 5$ hours \\
Papaya (Carica papaya L.) & Formosa & $\mathrm{YP} / \mathrm{NI}$ & $70^{\circ} \mathrm{C} / 6$ hours \\
Melon (Cucumis melo L.) & Cantaloupe & $\mathrm{OP} / \mathrm{NI}$ & $70^{\circ} \mathrm{C} / 6$ hours \\
Pineapple (Ananas comosus L.) & Perola & YP/NI & $70^{\circ} \mathrm{C} / 8$ hours \\
\hline
\end{tabular}

NI: No injuries; GP: green predominant; YP: yellow predominant; OP: orange predominant

The fruits were washed in water with mild detergent, then manually peeled. The peels were sanitized with sodium hypochlorite. After sanitization, about $500 \mathrm{~g}$ of each peel was dried in a forced circulation oven (Quimis, model 314D222, Brazil) as described in Table 1. The drying performance was established so that papaya, melon, and pineapple presented final moisture contents of $11 \%$ and mango $12 \%$, which are the same moisture values as described by MORAES and co-workers (2012) in their work on the dehydration of fruits. The determination of the final moisture was performed using a portable water activity measuring device (Aqualab, USA). After drying, the peels were subjected to crushing using a semi-industrial depulper (Arno, Brazil). The flours were stored protected from light in polyethylene containers in a freezer $\left(-20^{\circ} \mathrm{C}\right)$ until analysis.

Analyses of the bioactive compounds occurred from the following aspects: ascorbic acid (Strohecker \& Henning, 1967), lycopene and $\beta$-carotene (NAgata \& Yamashita, 1992), total extractable polyphenols (LARRAURI et al., 1997), and antioxidant activity (RE et al., 1999).

Analyses of the minerals: potassium, calcium, magnesium, iron, copper, manganese, and zinc were performed. The operating conditions for the analysis and quantification of the mineral contents and their respective references are summarized in Table 2. The digestion of the samples for the determination of the minerals was performed in a hotplate, which was administered consecutive rising temperatures until $220^{\circ} \mathrm{C}$, as described by Silva (1999). The minerals were determined by atomic absorption spectrometry, flame photometry (Analyser, model 910M, Brazil), and a flame atomic absorption spectrometer (Atomic, model GBC-933 Plus, USA).

All analyses were performed in triplicate. For comparison of averages, the analysis of variance (ANOVA) and Tukey's test were performed. The Pearson correlation test was used to evaluate the correlation between the compounds and the antioxidant activity. All statistic tests were performed using the software Assistat 7.6 beta. The significance level was of 5\% probability $(\mathrm{P}<0.05)$. 
Table 2. Operating conditions used in the quantification of minerals in mango, papaya, melon,

\begin{tabular}{|c|c|c|c|c|}
\hline Mineral & Technique & $\lambda_{\mathrm{nm}}$ & Linear range & Reference \\
\hline $\mathrm{Na}$ & $\mathrm{FP}$ & 589.0 & - & AOAC (1980) \\
\hline $\mathrm{K}$ & FP & 766.5 & - & AOAC (1980) \\
\hline $\mathrm{Ca}$ & AAS & 422.7 & $1.0-5.0 \mathrm{mg} \mathrm{l}^{-1}$ & Welz (1999) \\
\hline $\mathrm{Mg}$ & AAS & 285.2 & $0.1-0.5 \mathrm{mg} \mathrm{l}^{-1}$ & WeLz (1999) \\
\hline $\mathrm{Fe}$ & AAS & 248.3 & $1.0-5.0 \mathrm{mg} \mathrm{1}^{-1}$ & CHRISTIAN (2003) \\
\hline $\mathrm{Cu}$ & AAS & 324.7 & $0.03-10 \mathrm{mg} \mathrm{l}^{-1}$ & Welz (1999) \\
\hline $\mathrm{Mn}$ & AAS & 279.5 & $1.0-5.0 \mathrm{mg} \mathrm{l}^{-1}$ & Welz (1999) \\
\hline $\mathrm{Zn}$ & AAS & 213.9 & $0.1-0.4 \mathrm{mg}^{-1}$ & Welz (1999) \\
\hline
\end{tabular}

FP: Flame photometry; AAS: atomic absorption spectrometry

\section{Results and discussion}

\subsection{Bioactive compounds and antioxidant activity}

The papaya peel flour presented the highest amount of ascorbic acid among those studied (Table 3). No significant difference $(\mathrm{P}<0.05)$ between the ascorbic acid content of the flours prepared with mango, melon, and pineapple peels were observed. It is important to underline the high levels of ascorbic acid observed in the present study, since this compound is heat sensitive and may suffer oxidation and/or thermal degradation during processing (IVERSEN, 1999). The observed values in the flours prepared with mango, papaya, melon, and pineapple peels were quite high, corresponding to $50,80,40$, and $50 \%$, respectively, of the recommended daily intake (RDI) of this compound, which is $60 \mathrm{mg}$ based on a 2000 calorie intake (FDA, 2013).

\begin{tabular}{|c|c|c|c|c|c|}
\hline ruit & $\begin{array}{l}\text { Ascorbic acid } \\
(\mathrm{mg} / 100 \mathrm{~g})\end{array}$ & $\begin{array}{l}\text { Lycopene } \\
(\mu \mathrm{g} / 100 \mathrm{~g})\end{array}$ & $\begin{array}{l}\beta \text {-Carotene } \\
(\mu \mathrm{g} / 100 \mathrm{~g})\end{array}$ & $\begin{array}{l}\text { Total extractable } \\
\text { polyphenols } \\
\left(\mathrm{mg} \mathrm{GA} 100 \mathrm{~g}^{-1}\right)\end{array}$ & $\begin{array}{c}\text { Antioxidant } \\
\text { activity }(\mu \mathrm{M} \\
\left.\text { Trolox } \mathrm{g}^{-1}\right)\end{array}$ \\
\hline Mango & $31.00 \pm 3.05^{\mathrm{b}}$ & $25.74 \pm 0.01^{b}$ & $104.50 \pm 0.05^{\mathrm{b}}$ & $5459.10 \pm 48.00^{\mathrm{a}}$ & $402.05 \pm 2.81^{\mathrm{a}}$ \\
\hline apaya & $48.70 \pm 5.16^{\mathrm{a}}$ & $225.49 \pm 0.01^{\mathrm{a}}$ & $208.45 \pm 0.03^{b}$ & $2281.70 \pm 242.40^{b}$ & $41.69 \pm 1.60^{\mathrm{b}}$ \\
\hline Melon & $26.27 \pm 2.28^{\mathrm{b}}$ & $64.53 \pm 0.02^{b}$ & $821.45 \pm 0.08^{\mathrm{a}}$ & $919.07 \pm 45.90^{\mathrm{c}}$ & $27.40 \pm 2.97^{\mathrm{c}}$ \\
\hline ineapple & $29.70 \pm 0.26^{\mathrm{b}}$ & ND & $110.70 \pm 0.01^{\mathrm{b}}$ & $770.33 \pm 10.35^{\mathrm{c}}$ & $31.82 \pm 1.36^{\mathrm{c}}$ \\
\hline
\end{tabular}

Means in the same column followed by different letters differ significantly by Tukey test at 5\% probability. Mean values \pm standard deviation expressed in a dry matter basis. ND: Not detected; GA: gallic acid

Carotenoids were only detected in mango, papaya, and melon, the highest values were observed in papaya (Table 3). 


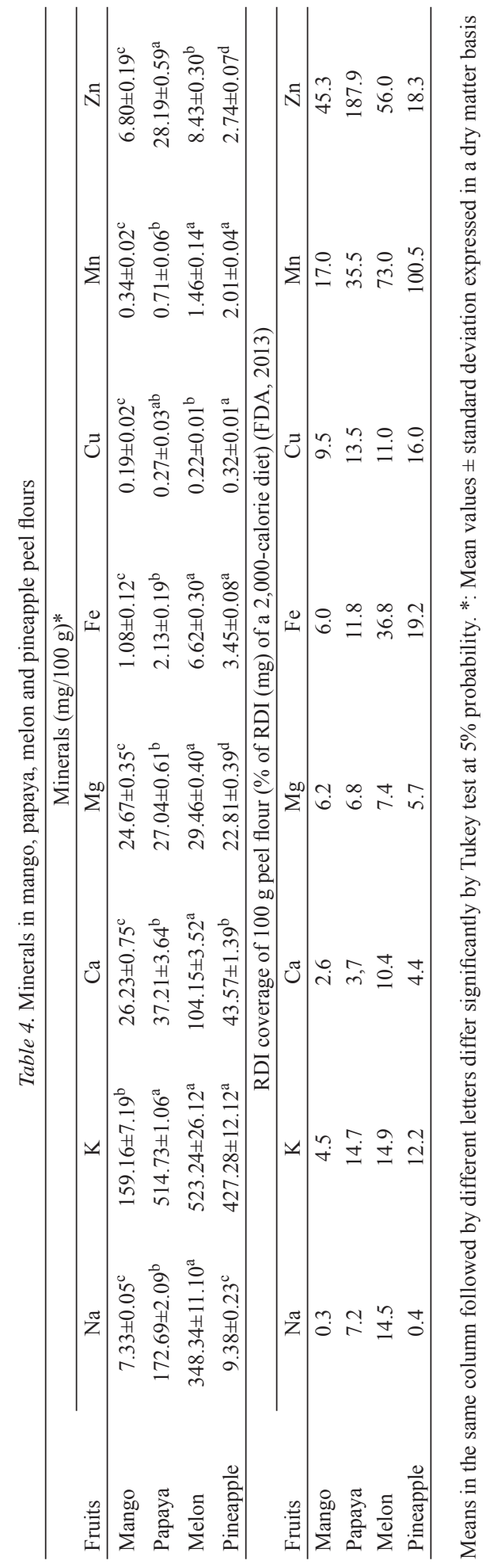


Regarding the antioxidant activity, the mango peel flour stands out (Table 3). Sogi and co-workers (2013) studied the effect of different drying methods on the antioxidant activity of the mango peel, and observed averages of 1724 and 1233 Trolox $\mu \mathrm{M} \mathrm{g}^{-1}$ in the peel of mango dried by lyophilization and cabin dryer, respectively. The difference between the results of this work and the work of SoGi and co-workers (2013) was expected, since applying heat during the drying process reduces the content of certain bioactive compounds, and as a result, reduces the antioxidant activity of the product (AmAN et al., 2005).

\subsection{Minerals}

The mineral content of the peel flours and their contribution to the recommended daily intake of these minerals can be seen in Table 4.

The sodium content in the studied fruit peel flours is low, which is important, since the excessive intake of sodium is related to the development of chronic diseases (WHO, 2007).

For the mineral potassium, the highest amount was observed in the melon peel flour (Table 4). SoARES and co-workers (2004) studied the potassium content in a concentrate juice of mango and observed values of $140 \mathrm{mg} / 100 \mathrm{~g}$, lower than that observed in the present study (159.16 $\pm 7.19 \mathrm{mg} / 100 \mathrm{~g})$.

The level of zinc in the fruit peel flours studied is important, because, in addition to providing high amount of the RDI, this mineral also has favourable participation in antioxidant defense (Prasad, 2007).

The high difference in the content of minerals, bioactive compounds, and antioxidant activity of pulp fruit when compared to their peels is expected, since there are many reports in the literature confirming that the nutrients and antioxidant compounds are found mainly in the fruit peels and seeds (Melo et al., 2008; Silva et al., 2014). Thus, knowing that many of these compounds bring beneficial effects to the body, the ingestion of peels and seeds in the daily diet becomes important to health.

\subsection{Correlations between the studied components}

The Pearson correlation analysis between the minerals copper $(\mathrm{r}=0.730, \mathrm{P}=0.040)$ and manganese $(r=0.742, \mathrm{P}=0.035)$ presented positive correlation with the antioxidant activity, while magnesium presented negative correlation $(\mathrm{r}=-0.757, \mathrm{P}=0.030)$. The high level of copper caused a reduction of the numbers of tumors cells in tissues (GRIGOLO et al. 1998), which characterizes an antioxidant activity of this mineral. A higher positive correlation with the antioxidant activity was observed for total extractable polyphenols $(\mathrm{r}=0.952, \mathrm{P}=0.000)$. This positive correlation between phenolic compounds and antioxidant activity was also observed in other studies (SANTOS et al., 2010; Contreras-CALDERon et al., 2011).

High values of correlations were observed between the minerals magnesium and sodium $(\mathrm{r}=0.949, \mathrm{P}<0.0001)$, and iron and calcium $(\mathrm{r}=0.978, \mathrm{P}<0.0001)$.

It is important to emphasize the positive correlation between the bioactive compounds and some minerals, as observed among ascorbic acid and zinc $(\mathrm{r}=0.873, \mathrm{P}=0.000)$, lycopene and potassium $(\mathrm{r}=0.653, \mathrm{P}=0.041)$, lycopene and zinc $(\mathrm{r}=0.974, \mathrm{P}<0.0001), \beta$-carotene and sodium ( $\mathrm{r}=0.921, \mathrm{P}<0.0001), \beta$-carotene and calcium $(\mathrm{r}=0.978, \mathrm{P}<0.0001), \beta$-carotene and iron $(\mathrm{r}=0.919, \mathrm{P}<0.0001), \beta$-carotene and magnesium $(\mathrm{r}=0.855, \mathrm{P}=0.001)$, total extractable polyphenols and copper $(\mathrm{r}=0.871, \mathrm{P}=0.005)$.

No studies of Pearson correlation analysis between bioactive compounds and minerals can be found in the literature. As the Pearson correlations for these compounds have not been 
determined for individual peel flours in this study, the data presented here is not sufficient to confirm such relationships. However, revealing such potential connections between minerals and bioactive compounds or minerals and minerals could be subjects of further research.

\section{Conclusions}

The evaluation of the tropical fruit peels flours showed that, in general, these industrial wastes have significant amounts of bioactive compounds, antioxidant activity, and minerals.

Thus, their use is recommended for food applications through their addition to other food products, adding value and bringing potential nutritional benefits to the health. These materials can be converted into commercial products or raw materials for secondary processes, which are justified not only by the composition, but also by the availability and low price of these products. There are several possible uses of these products, for example, for the preparation of cookies, pasta, and cereal bars, however it is necessary to realize specific toxicological studies that will actually guarantee and prove the safety of their use for consumers.

\section{References}

Aman, R., Schieber, A. \& Carle, R. (2005): Effects of heating and illumination on trans-cis isomerization and degradation of $\beta$-carotene and lutein in isolated spinach chloroplasts. J. Agric. Food Chem., 53, 9512-9518.

AOAC (1980): Official methods of analysis, $13^{\text {th }}$ ed., Association of Official Analytical Chemists - AOAC International, Washington, 1015 pages.

Christian, G.D. (2003): Analytical chemistry, $6^{\text {th }}$ ed., John Wiley \& Sons: New York, 848 pages.

Contreras-Calderon, J., Calderón-Jaimes, L., Guerra-Hernández, E. \& García-Villanova, B. (2011): Antioxidant capacity, phenolic content and vitamin $\mathrm{C}$ in pulp, peel and seed from 24 exotic fruits from Colombia. Food Res. Int., 44, 2047-2053.

Felipe, E.M. de F., Costa, J.M.C. DA, MaiA, G.A. \& Hernandez, F.F.H. (2006): Avaliação da qualidade de parâmetros minerais de pós-alimentícios obtidos de casca de manga e maracujá (Evaluation of quality of the mineral parameters of food powders from mango skin and passion fruit rind). Alim Nutr., 17, 79-83.

FDA (2013): Food and Drug Administration Appendix F: calculate the percent daily value for the appropriate nutrients.Available at: http://www.fda.gov/food/guidanceregulation/guidancedocumentsregulatoryinformation/ labelingnutrition/ucm064928.htm (last accessed 23 Nov. 2013).

Galindo-Estrella, T., Hernández-Gutiérrez, R., Mateos-Díaz, J., Sandoval-Fabián, G., Chel-Guerrero, L., Rodríguez-Buenfil, I. \& Gallegos-Tintoré, S. (2009): Proteolytic activity in enzymatic extracts from Carica papaya L. cv. Maradol harvest by-products. Process Biochem., 44, 77-82.

Grigolo, B., Lisignoli, G., Toneguzzi, S., Mazzetti, I. \& Facchini, A. (1998): Cooper/zinc superoxide dismutase expression by different human osteosarcoma cell lines. Anticancer Res., 18, 1175-1180.

IvERSEN, C.K. (1999): Black currant nectar: effect of processing and storage on anthocyanin and ascorbic acid content. J. Food Sci., 64, 37-41.

Larrauri J.A., Rupérez, P. \& Saura-Calixto, F. (1997): Effect of drying temperature on the stability of polyphenols and antioxidant activity of red grape pomace peels. J. Agric. Food Chem., 45, 209-215.

Matias, M.F.O., Oliveira, E.L., Gertrudes, E. \& Magalhâes, M.A. (2005): Use of fibres obtained from the cashew (Anacardium ocidentale L.) and guava (Psidium guayava) fruits for enrichment of food products. Braz. Arch. Biol. Techn., 48, 143-150.

Melo, E.A., Maciel, M.I.S., Lima, V.A.G.L. \& Nascimento, R.J. (2008): Capacidade antioxidante de frutas (Antioxidant capacity of the fruit). Rev. Bras. Ciênc. Farm., 44, 193-201.

Moraes, L.R.V., Azevêdo, L.C., Santos, V.M.L. \& Leitão, T.J.V. (2012): Estudo comparativo da desidratação de frutas para fins de infusão, por método tradicional e liofilização (Comparative study of fruit dehydration for the purpose of infusion by traditional method and lyophilization). Rev. Semiárido Visu., 2, 254-264. 
NaGATA, M. \& Yamashita, I. (1992): Simple method for simultaneous determination of chlorophyll and carotenoids in tomato fruit. J. Jpn. Soc. Food Sci. Techn., 39, 925-928.

O'Shea, N., Arendt, E.K. \& Gallagher, E. (2012): Dietary fibre and phytochemical characteristics of fruit and vegetable by-products and their recent applications as novel ingredients in food products. Innov. Food Sci. Emerg., 16, 1-10.

Prasad, A.S. (2007): Zinc: mechanisms of host defense. J. Nutr., 137, 1345-1349.

Re, R., Pellegrini, A.P., Pannala, A., Yang, M. \& Rice-Evans, C. (1999): Antioxidant activity applying an improved ABTS radical cation decolorization assay. Free Radical Bio. Med., 26, 1231-1237.

Santos, G.M., Maia, G.A., Sousa, P.H.M., Figueiredo, R.W., Costa, J.M.C. \& Fonseca, A.V.V.F. (2010): Atividade antioxidante e correlações com componentes bioativos de produtos comerciais de cupuaçu (Antioxidant activity and correlations with bioactive components from commercial products of cupuaçu). Cienc Rural., 40, 1636-1642.

SiLVA, F.C. (1999): Manual de análises químicas de solos, plantas e fertilizantes (Manual of chemical analysis of soils, plants, and fertilizers). Brasília: Embrapa Comunicação para Transferência de Tecnologia/ Embrapa Solos/ Embrapa Informática para Agricultura, 370 pages.

Silva, L.M.R. DA, Figueiredo, E.A.T. de, Ricardo, N.M.S., Vieira, I.G.P., Figueiredo, R.W. DE, Gomes, C.L. (2014): Quantification of bioactive compounds in pulps and by-products of tropical fruits from Brazil. Food Chem., 143, 398-404.

Soares, L.M.V., Shishido, K., Moraes, A.M.M. \& Moreira, V.A. (2004): Composição mineral de sucos concentrados de frutas brasileiras (Mineral composition of Brazilian fruit juice concentrates). Cienc. Tecnol. Aliment., 24, 202-206.

Sogi, D.S., Siddie, M., Griby, I. \& Dolan, K.D. (2013): Total phenolics, antioxidant activity, and functional properties of 'Tommy Atkins' mango peel and kernel as affected by drying methods. Food Chem., 141, 26492655.

SousA, M.S.B., VIEIRA, L.M., SiLVA, M. DE J.M. DA \& LIMA, A. DE. (2011): Caracterização nutricional e compostos antioxidantes em resíduos de polpas de frutas tropicais (Nutritional characterization and antioxidant compounds in pulp residues of tropical fruit). Ciênc. Agrotec., 35, 554-559.

Strohecker, R. \& Henning, H.M. (1967): Analises de vitaminas: Métodos comprobados (Vitamin analysis: confirmed methods), Madrid: Paz Montalvo, 428 pages.

Uchoa, A.M.A. de, Costa, J.M.C. da, Maia, G.A., Silva, E.M.C., Carvalho, A. de F.F.U. \& Meira, T.R. (2008): Parâmetros físico-químicos, teor de fibra bruta e alimentar de pós alimentícios obtidos de resíduos de frutas tropicais (Physico-chemical parameters and crude and dietary fibre contents of edible powders from tropical fruit residues). Segurança Alimentar Nutricional., 15, 58-65.

Welz, B. (1999): Atomic absorption spectrometry, $3^{\text {rd }}$ ed., VCH, Deerfield, 941 pages.

WHO (2007): Report of a WHO forum and technical meeting, 2006; Paris, France. Reducing salt intake in populations. World Health Organization Geneva, WHO. 